\title{
Tackling Causes of Frequent Building Collapse in Nigeria
}

\author{
S.A. Oloyede \\ Department of Estate Management, School of Environmental Sciences \\ College of Science and Technology, Covenant University, Ota. Ogun State, Nigeria \\ Tel: +234 (0) 8034722469 E-mail: samoloye49@yahoo.com

\section{C.B. Omoogun} \\ Department of Estate Management, School of Environmental Sciences \\ College of Science and Technology, Covenant University, Ota. Ogun State, Nigeria \\ Tel. +234 (0) $8023216096 \quad$ E-mail: tundeomoogun@yahoo.co.uk \\ O.A. Akinjare \\ Department of Estate Management, School of Environmental Sciences \\ College of Science and Technology, Covenant University, Ota. Ogun State, Nigeria \\ Tel: +234 (0) 8038065545 E-mail: omoladeogah@yahoo.co.uk
}

\begin{abstract}
A building, once properly constructed is expected to be in use for a very long time. Although every society has its own problems and Nigeria is not an exception yet the very recent challenges of buildings collapsing in various locations have been giving the various arms of government and the people of Nigeria sleepless nights in view of the enormous loss of huge investments in housing, properties and human life. The major challenge on the issue of building collapse is that individuals differ radically from one another on the professional to blame as the major cause of the collapse of a building. This study reviews current challenges in the building industry in relation to collapse of buildings, loss of lives and properties. Data for the study were obtained through structured questionnaires administered to landlords and professionals in the construction industry in addition to academia in the built environment. Historical data of past collapsed buildings in Nigeria were also discussed. Findings from the three prominent groups were varied. First, building experts blamed building collapses on the use of low quality building materials coupled with employment of incompetent artisans and weak supervision of workmen on site. Second, public opinion revealed that the blames of building collapse were due to non-compliance with specifications/standards, use of substandard building materials and equipments and the employment of incompetent contractors. Third, opinion of the academia on remote causes of building collapse showed that the route causes are mainly the non-enforcement of existing laws and endemic poor work ethics of Nigerians at large. The study recommends that the press should lay more emphasis on educating the public at large on the dangers of the collapse of a building and less on public emotions. In addition, government should, on one hand, embark on proactive steps by mustering enough political will to allow the Town Planning Authorities to perform their functions unfettered and on the other hand, provide the legal framework that can improve and ensure smoother, less time-consuming and less burdensome ways to conduct business in the functioning of law courts.
\end{abstract}

Keywords: Building materials, Supervision, Workmanship, Nigeria

\section{Introduction}

Individual opinions differ radically from one another on the professional to blame for building collapse. By grace, Nigeria is not yet famous as a country ravaged by natural disasters like other countries however, the country is not without her own share of disasters, which are chiefly man-made (Falobi, 2009). The world is however becoming dangerous as a result of the geometrical order of population growth, urban development in coastal areas, poor planning and housing developments in high risk areas of the city. In recent times, the incidence of building collapse in the country's major cities of Lagos, Abuja and Port Harcourt have been alarming. Lagos, the major commercial nerve center of the country, has recorded four cases in 2006 with two of such collapses in Ebute Metta that claimed 37 lives included residential buildings. Adegoroye (2006) reports that on Saturday March 25, the Nigerian Industrial Development Bank's building collapsed killing two persons and injuring 23 others. In November, 2007, a two-storey building collapsed along Okegbogbo Street while another two 
six-storey buildings along Imam Ligali Street in Lagos Island collapsed, affecting two other six-storey buildings. The aftermath of the incidence left fifteen persons injured and one dead.

\section{The Nigerian Status Quo}

Buildings, like all structures, are designed to support and withstand certain loads without any deformity. The loads are the weights of people and objects, the intensity of rain and the varing wind pressure. With buildings of a few floors, strength generally accompanies sufficient rigidity, and the design is mainly that of a roof that keeps the weather out while spanning large open spaces. With tall buildings of many floors, foundation, which supports the building itself, is of major consideration as tall buildings are subject to catastrophic collapse. Akosile (2010) noted that Chekwuneke noted that building "collapse occurs when the structural frame of a building breaks up when the loads on it are beyond its carrying capacity".

Government has put in place specific rules and regulations required to maintain a sense of safety of buildings to prevent disastrous occurrences in addition to generally ensure that players and referees in the building construction industry abide by certain accepted standards of moral conduct and good behaviour. For accountability purposes especially as it relates to proper observance of Town Planning rules and regulations, those administering the rules must be held responsible and accountable for their actions. However, accountability in Nigeria is generally weak because of the lack of the political will to enforce same and this view was supported by Dare (2009) when he stated in his article on the challenges of journalism that watchdog organizations that provide information on the built environment such as the press, and other civil society organizations, are sometimes suppressed.

In the same vein, Usoro and Usoro (2003) pointed to the Nigerian Head of State accusing the press of being too critical of his government. He particularly accused the press of acting like a colonial press. When people in high places in government are intolerant of genuine accusations, one begins to wonder how genuine activities that are germane to peaceful co-existence and prosperity can flourish unhindered. In Nigeria, the common causes of building collapse have been traced to bad design; faulty construction; foundation failure; extraordinary loads, use of unqualified contractors and poor project monitoring and above all, lack of enforcement of building codes by the relevant Town Planning Officials (Badejo,2009; Falobi, 2009; Bamidele, 2000).

\section{Literature Review}

Several causes of building failure had been attributed to either natural or man-made phenomena. A natural phenomenon may consist of earthquakes and typhoons while man-made phenomena consist of disasters which maybe borne out of man's negligence may in areas such as soil type, building design and planning for extra ordinary loads and stress from strong winds and earthquake for tall buildings, foundation works, quality of building materials, strict monitoring of craftsmen and quality of workmanship.

Different soil types pose varying problems for built foundations and the structural integrity of an entire building. McCarthy (1999) noted that there is therefore a need to carry out soil surveys to ascertain the compressibility or consolidation potentials as well as the bearing strength of the soil of a particular site. Movements often result in sand and clayey sites because there are too many voids between their particles. Silt deposits are susceptible to collapse if exposed to excessive amounts of water while clays shrink in the dry season only to swell during the wet season or in the constant presence of water. The points made by McCarthy (1999) were not unexpected. However, any contractor worth his salt would take all these points into consideration while laying the foundation of a building. The challenge in most cases is the human error of poor monitoring of works on site. Uzokwe (2001) observed that the cause of a building failure is unique to each building but summarized the various causes of building collapse as due to the quality of the blocks used, quality of concrete used, poor compaction and consolidation of foundation soil, weak soil. The paper has also added its voice to the poor attitude to professional ethics in that a qualified site engineer ought to know what is expected of him when inferior building materials are delivered to site.

Structural failure in buildings, in broad terms comes in various forms and degrees of severity; the worst of which is a collapse. Deterioration or decay especially of vigour or usefulness of a building can be categorized as a failure of some sort but a total loss of bearing strength resulting in a sudden breakdown, physical depletion and/or falling apart is termed a collapse. Among these factors are greed, incompetence, corruption, poor planning, poor enforcement of building codes, inadequate public awareness and education, and limited financial and technical resources (Falobi, 2009). The collapsed buildings were found to be constructed with low quality building materials, incompetent craftsmen rather than professionals were found to be engaged while the existing building codes, meant to guide builders were rendered ineffective because of lack of political will to enforce same by the Town Planning Authorities. 
According to Adebayo (2000), the skill, experience and personal ability of the workmen involved in the building construction is of utmost importance in creating value. The so-called ready-made hollow sandcrete blocks sold by some block-making industries do not measure up to standard as a result of anticipated abnormal profits. Once these lapses are tolerated intentionally or otherwise, the quality of the sub-structure or super-structure cannot be guaranteed. The quality of the workmen is a measure of their effectiveness and efficiency at all times during construction while the level of building maintenance after its occupation depends on the performance of workmen. The conclusion of Adebayo (2000) can only be relied upon where the building developer or the contractor are capable and willing to appreciate quality and ready to pay for same. In addition, he must be willing to deliver high quality building materials to site in required quantities coupled with strict supervision of workmen by the Site Supervisor.

\section{Research Methods}

Primary data were collected through questionnaires distributed among various seasoned professionals involved in the building industry (Contractors, Builders, Architects, Estate Surveyors and Valuers, Civil Engineers, Electrical Engineers, Structural Engineers and Town Planners). Ten members of each profession listed earlier were selected using purposeful sampling and given questionnaires to fill. In addition, fifty landlords each, selected purposively, within the inner cities of Ota, Ogun State and Ijaiye, Ojokoro, Lagos State were given questionnaires to solicit information regarding their experiences regarding collapsed buildings. Historical data of buildings that that had collapsed in the past as discussed in various newspapers, previous research works and the Nigerian Institution of Building were also collated. The opinion of the Zonal Town Planning Officer of Alimosho Zonal Town Planning Authority on implications of sites susceptible to foundation challenges were also sought by way of in-depth interviews. Bricklayers, carpenters, welders, plumbers and electrical contractors were interviewed as to what they perceived as the major causes of building collapse in the country. The data so collated were analysed using descriptive and analytical statistics.

\section{Data Analysis and Discussion}

Information gathered were analysed as shown in Tables 1 to 3 . Table $1 \mathrm{x}$-rays the reasons adduced by building professionals on the immediate causes of building collapses. These reasons include soil type, poor building design and planning, use of low quality building materials, use of incompetent craftsmen leading to poor workmanship, weak supervision and natural disaster. Going by the reasons adduced, the use of low quality building materials ranked first coupled with the employment of incompetent craftsmen and artisans under very weak supervision on site. A follow up in-depth interview among site workers showed that much as poor workmanship can be traced to workers on site, greed, corruption, ignorance can be traced to many contractors who, for selfish reasons, fail to adhere strictly to building specifications and standards either as a result of their incompetence or greed.

Poor building design and planning came fourth with natural disaster and soil type following. An in-depth interviewed conducted among the listed professionals showed a bias of one professional to another. Each profession tries to justify its sincerity of purpose and laying blame at the door step of another profession on the basis of greed, incompetence, corruption, inadequate supervision and ignorance pervading the rank and file of society. If emotions could be incarcerated by hiding professional complexity, at least professionals' expressions in writing could liberate and display our authenticity. It was for this reason that the second questionnaire was designed and distributed among fifty landlords each, selected purposively, within the inner cities of Ota, Ogun State and Ijaiye, Ojokoro, Lagos State to solicit information regarding their experiences regarding collapsed buildings. Data generated were analysed as in Table 2.

\section{Findings}

The causes of building failure, from the public view can be summarized under improper design, incompetent contractor, faulty construction methodology, poor Town Planning approval /development monitoring process; non-compliance with specifications/standards by developers/contractors; use of substandard materials and equipments; inadequate supervision or inspection/monitoring, economic pressures, incompetent conversion, change of use of buildings, aged buildings, poor maintenance culture. Data analysis of these factors showed that non-compliance with specifications/standards by developers/contractors; employment of incompetent contractor and use of substandard materials and equipments were the three prominent causes of building collapses witnessed in Nigeria.

This finding can be attributed also to the insurgence of inexperienced, stingy or over bearing building developers who issue instructions concerning the way and manner building works should be carried out on site which at times may not be in the overall interest of the project. Finally, once suppliers of building materials are able to 
penetrate and influence the contractor by offering gratification as a subtle way of delivering low quality building materials, the door is then open for possible future challenges to the stability of the structure.

As a third means of assessing the remote causes of building collapse, the opinion of stakeholders in the academia was sought. These remote causes include falling standard of education; lack of continuing professional development; non-enforcement of existing laws; endemic poor work ethics and bribery and corruption. Academicians in the built environment were of the opinion that the non-enforcement of existing laws by the Town Planning Authorities as a result of the lack of political will by the various arms of government has been the number one factor. This is closely followed by the endemic poor work ethics among Nigerians as a result of the ever increasing demand for more pay in view of the ever rising cost of living for the average Nigerian. The other three factors- falling standard of education; lack of continuing professional development and bribery and corruption were considered as insignificant.

\section{Recommendations}

Safety of life, property and fund invested in housing can only be guaranteed if the following three recommendations are feely accepted and implemented. First, the collapse of buildings cannot be totally eradicated but can be minimized if public emotions can be played down and the press can lay more emphasis on educating the public at large on the dangers of the collapse of a building. The public must be willing to alert government on buildings suspected to be a risk to the lives of people living within a neighbourhood.

Government must be ready to tackle the complicated problem of building neglect by the populace generally. The way to tackling the problem of building neglect should be multi-pronged, covering the four major areas: Legislation, enforcement, support and assistance, publicity and public education. To achieve this, government must provide and maintain a modernised, efficient and user-friendly statutory building control regime to meet the residential housing development needs of Nigerians. In addition, government should review enforcemnet policy against building problems that are of public concern, including the issue of sub divided units and water seepage in order to enhance building safety. Government long term objective should be to foster a building safety culture amongst nigerians so that all stakeholders involved, building owners, occupants, buikding professional, contractors and workers) will posses the self-awareness to properly observe building safety. A sfe built environment can only be sustained if all concerned in our community responsively play their part.

Second, government must embark on proactive steps by mustering enough political will to allow the Town Planning Authorities perform their functions unfettered. Government must realize that for the oversight bodies to be effective, they have to be created in a political atmosphere where leaders are honest, civil servants are insulated from political interference, and better incentives are provided to discourage corruption

Four, to check the activities of erring professionals, members of staff of the Town Planning Authority and individual housing developers, the legal framework should be improved to ensure smoother, less time-consuming and less burdensome ways to conduct business in the functioning of law courts. Once this is put in place, those who flout the law can be promptly and heavily sanctioned to ensure strict compliance. Unending court cases over misbehavior should be discouraged by the judiciary if the present tempo of building collapse is to be reversed.

\section{Conclusions}

Politicians, the press, members of the civil service and the community have various roles to play in tackling building collapse phenomenon in Nigeria. Building construction is a delicate, sophisticated and complex process, where failure to adhere strictly to laid-down proceedures can result in building collapse. For this reason, therefore all concerned individuals in building construction should ensure that they acquire adequate training and knowledge to understand the techniques of construction so as to reduce and subsequently eliminate the incidence of building collapse in the country.

However, the society, going by cultural characteristics have several attributes that can be used to facilitate the success of building sustainability. When these human attributes are considered in conjunction with intentions of future building investors, designers, development professionals coupled with housing project incentives, building codes and construction standards enduring buildings will surely be attained in the very near future.

\section{References}

Adebayo, S.O. (2000). "Improving Building Techniques" Proceedings of a Workshop on Building Collapse: Causes, Prevention and Remedies. The Nigerian Institute of Builders, Lagos State*******

Adegoroye, B. (2010). "Disaster Everywhere". Daily Sun Newspapers, Retrieved from http://www.dailysun newspaperonline.com/webpages/news/national/2006/mar/25/national-25-03-2006-006.htm 
Akosile, A. (2010, March 26). "Structural Engineers Advocate Stricter Building Construction Measures". Thisday Newspapers, Retrieved from http:// www.thisdayonline.com /archive/2002/03/26/20020326est 02.html

Badejo, E. (2009, July 13). "Engineers, Others Urge Multi-disciplinary Approach to Curb Building Collapse". The Guardian Newspapers, Retrieved from http://www.naijaproperties.com/news_95php

Bamidele, O.T. (2000, Feb.,18). "Building Collapse: Stakeholders Proffer Solutions on Way Forward". Daily Sun Newspapers, Retrieved from http://www.dailysunngr.com

Dare. (2009, July16). "Narating the Nigerian Story: The Challenge of Journalism" The Nation Newspapers, Retrieved from http://www.thenationnewspapers.ng

Falobi, F. (2009 July, 20). "Nigeria: Tackling Disaster at Grassroots in Lagos" Daily Independent Newspaper, Retrieved from http://www.dailysunnewspapers.ng

McCarthy, D.F. (1999). Essentials of Soil Mechanics and Foundations. Cited in Criteriurn McCarthy Engineers.Odulami, A.A. (2002) Building Material Specification and Enforcement on Site in D.R. Ogunsemi (Ed) Building Collapse: Causes, Prevention and Remedies. Nigeria Building Institute, Ondo State pp22-27

Myint, U. (2000). Corruption: Causes, Consequences and Cures. Asia-Pacific Development Journal, 7( 2), 33-58.

Tattersall, N. (2009 June, 28). “ Nigeria Building Collapse Kills at Least Five-Rescuers”. Daily Sun Newspapers, Retrieved from http://www.Dailysun.ng

Usoro, B. and Usoro, P. (2003 Nov., 8). Press Singing and Praise Freedom. Saturday Sun Newspaper, p. 23.

Uzokwe, O.A. (2001). "Rising Incidence of Building Collapse in Nigeria: Any Remedy?" Nigeria World 1999-2010

Wardhana and Hadipriono F.C. (2003). Study of Recent Building Failures in The United States. Journal of Performance of Constructed Facilities 17(3), 151-158. Retrieved from American Society of Civil Engineers Research Library Database.

Table 1. Reasons for Building Collapse from Real Estate Professionals

\begin{tabular}{|c|c|c|c|c|c|c|}
\hline \multirow[t]{2}{*}{ Professionals } & \multicolumn{5}{|c|}{ Reasons for building collapse } & \multirow[b]{2}{*}{$\begin{array}{l}\text { Natural } \\
\text { disaster }\end{array}$} \\
\hline & $\begin{array}{l}\text { soil } \\
\text { type }\end{array}$ & $\begin{array}{l}\text { Poor } \\
\text { building } \\
\text { design and } \\
\text { planning }\end{array}$ & $\begin{array}{l}\text { Use of Low } \\
\text { quality } \\
\text { building } \\
\text { materials }\end{array}$ & $\begin{array}{l}\text { Use of incompetent } \\
\text { craftsmen leading to } \\
\text { poor workmanship }\end{array}$ & $\begin{array}{l}\text { Weak } \\
\text { supervision }\end{array}$ & \\
\hline Town Planners & 30 & 10 & 65 & 70 & 55 & 20 \\
\hline $\begin{array}{l}\text { Estate Surveyors } \\
\text { and Valuers }\end{array}$ & 10 & 25 & 75 & 65 & 85 & 10 \\
\hline $\begin{array}{l}\text { Structural } \\
\text { Engineers }\end{array}$ & - & 35 & 55 & 45 & 55 & 10 \\
\hline $\begin{array}{l}\text { Electrical } \\
\text { Engineers }\end{array}$ & 25 & 40 & 60 & 65 & 55 & 10 \\
\hline Civil ngineers & 35 & 45 & 55 & 45 & 55 & 10 \\
\hline Architects & 10 & 10 & 55 & 60 & 35 & 35 \\
\hline Builders & 25 & 55 & 25 & 15 & 10 & 45 \\
\hline $\begin{array}{l}\text { Building } \\
\text { Contractors }\end{array}$ & 25 & 65 & 10 & 10 & 15 & 65 \\
\hline $\begin{array}{ll}\text { Average } & \text { score } \\
\text { in \%ages } & \end{array}$ & $\begin{array}{l}160 / 80 \\
0=20\end{array}$ & $\begin{array}{l}285 / 800=3 \\
6\end{array}$ & $400 / 800=50$ & $365 / 800=46$ & $365 / 800=46$ & $205 / 800=26$ \\
\hline Ranking & $6^{\text {th }}$ & 4th & $1 \mathrm{st}$ & 2 nd & 2 nd & 5 th \\
\hline
\end{tabular}


Table 2. Public Opinion on Factors influencing the Collapse of Buildings

\begin{tabular}{|c|c|c|c|c|c|c|c|}
\hline \multirow[t]{2}{*}{ Factors } & \multicolumn{5}{|l|}{ Perception } & \multirow[t]{2}{*}{$\begin{array}{l}\text { Aggregate } \\
\text { Score }\end{array}$} & \multirow[t]{2}{*}{ Ranking } \\
\hline & $\begin{array}{l}\text { Strongly } \\
\text { Agree }\end{array}$ & Agree & $\begin{array}{l}\text { Undecide } \\
\text { d }\end{array}$ & $\begin{array}{l}\text { Disagre } \\
\mathrm{e}\end{array}$ & $\begin{array}{l}\text { Strongly } \\
\text { Disagre } \\
\mathrm{e}\end{array}$ & & \\
\hline $\begin{array}{l}\text { Incompetent } \\
\text { contractors }\end{array}$ & 66 & 18 & 6 & 3 & 7 & 331 & 2 nd \\
\hline $\begin{array}{l}\text { Faulty construction } \\
\text { methodology }\end{array}$ & 45 & 20 & 6 & 13 & 16 & 282 & 5 th \\
\hline Improper design & - & 35 & 15 & 47 & 3 & 202 & 7 th \\
\hline $\begin{array}{l}\text { Poor Town Planning } \\
\text { approval /development } \\
\text { monitoring process }\end{array}$ & - & 6 & 4 & & 90 & 108 & 8 th \\
\hline $\begin{array}{l}\text { Non-compliance with } \\
\text { specifications/ } \\
\text { standards by } \\
\text { developers/contractors }\end{array}$ & 85 & 5 & & 10 & - & 375 & $1 \mathrm{st}$ \\
\hline $\begin{array}{lr}\text { Use of } & \text { substandard } \\
\text { materials } & \text { and } \\
\text { equipments } & \end{array}$ & 35 & 45 & 6 & 14 & - & 323 & $3 \mathrm{rd}$ \\
\hline $\begin{array}{l}\text { Inadequate supervision } \\
\text { or inspection/ } \\
\text { monitoring }\end{array}$ & 51 & 13 & 6 & 18 & 2 & 281 & 6th \\
\hline Economic pressures & - & 11 & 19 & 4 & 66 & 107 & 9th \\
\hline $\begin{array}{l}\text { Incompetent conversion, } \\
\text { change of use , poor } \\
\text { maintenance culture }\end{array}$ & 85 & 5 & 5 & 5 & - & 285 & 4 th \\
\hline
\end{tabular}

Table 3. Opinion of the Academia on Remote Causes of Building Collapse

\begin{tabular}{|l|l|l|l|l|l|l|l|}
\hline Remote Causes & $\begin{array}{l}\text { Strongly } \\
\text { Agree }\end{array}$ & Agree & Undecided & Disagree & $\begin{array}{l}\text { Strongly } \\
\text { Disagree }\end{array}$ & $\begin{array}{l}\text { Aggregate } \\
\text { Score }\end{array}$ & Ranking \\
\hline $\begin{array}{l}\text { Falling Standard of } \\
\text { education }\end{array}$ & 0 & 33 & 26 & 01 & 31 & 150 & 5 th \\
\hline $\begin{array}{l}\text { Lack of continuing } \\
\text { professional } \\
\text { development }\end{array}$ & 0 & 27 & 32 & 41 & 0 & 163 & 4 th \\
\hline $\begin{array}{l}\text { Non-enforcement of } \\
\text { existing laws }\end{array}$ & 88 & 12 & 0 & 0 & 0 & 388 & 1 st \\
\hline $\begin{array}{l}\text { Endemic poor work } \\
\text { ethics }\end{array}$ & 61 & 11 & 9 & 19 & 0 & 315 & 2 nd \\
\hline $\begin{array}{l}\text { Bribery and } \\
\text { corruption }\end{array}$ & 4 & 7 & 4 & 42 & 43 & 164 & 3 rd \\
\hline
\end{tabular}

